/www.coachorg.com/en/resourcecentre/resources/ COACH_Career_Matrix_2013_Final.pdf.

6. Health Informatics Professional Core Competences [Electronic resource]. - Toronto: Canada's Health Informatics Association, 2012. - 22 p. - Mode of access: http://www.coachorg.com/en/ resourcecentre/resources/Health-Informatics-CoreCompetencies.pdf.

7. Kushniruk A. et al. The School of Health Information Science at the University of Victoria: Towards an Integrative Model for Health Informatics
Education and Research / A. Kushniruk, F. Lau, E. Borycki, D. Protti // IMIA Yearbook of Medical Informatics. - 2006. - P. 159-165.

8. Lau F., Bell H. A pan-Canadian Health Informatics Education Strategy / F. Lau, H. Bell [Electronic resource]. - AMIA 2003 Symposium Proceedings. $-2003 .-$ P. 386-390. - Mode of access: https://www.ncbi.nlm.nih.gov/pubmed/14728200.

9. Welcome to the School of Health Information Science: Undergraduate Handbook. - University of Victoria, 2012. - $46 \mathrm{p}$.

Стаття надійшла до редакції 06.04.2018

УДК 378.147

DOI:

Вадим Рижиков, доктор педагогічних наук, професор, стариий науковий співробітник, Науково-дослідного иентру Військового інституту Київського начіонального університету імені Тараса Шевченка

\title{
МЕТОДИКА ВИКОРИСТАННЯ “МОЗКОВОГО ШТУРМУ" НА СЕМІНАРСЬКИХ ЗАНЯТТЯХ В ПРОФЕСІЙНІЙ ПІДГОТОВЦІ У ВИЩИХ ВІЙСЬКОВИХ НАВЧАЛЬНИХ ЗАКЛАДАХ (ВВНЗ)
}

Стаття присвячена використання інтерактивних методів навчання на прикладі “мозкового штурму” на семінарських заняттях при професійній підготовці у ВВНЗ майбутніх офіцерів. “Мозковий штурм” розвиває творчу активність, поліпшує якість теоретичних знань, сприяє формуванню емочійної стійкості, розвиває уміння висловлювати і обтрунтовувати власну професійну точку зору. При формуванні професійної готовності у майбутніх офіцерів в процесі підготовки у ВВНЗ, особливо слід звернути увагу на метод мозкового штурму (мозкової атаки), тому щзо це метод групового вирішення творчої проблеми. У ході його застосування формується здібність переборювати внутрішні бар'єри, перехід на чужу логіку, внаслідок чого творчі потенціали учасників ніби інтегруються, щзо особливо важливо для професійної діяльності військового в бойовій обстановиі.

Ключові слова: вищі військові навчальні заклади; семінарське заняття; “Мозковий штурм”; військовослужбовиі; професійна підготовка.

Рис. 1. Табл. 1. Лім. 9.

Vadym Ryzhykov, Doctor of Sciences (Pedagogy), Professor, Senior Researcher of the Research Center of Military Institute of Kyiv, National Taras Shevchenko University

\section{METHODOLOGY OF USING “BRAINSTORM” TECHNOLOGY DURING THE SEMINARS IN THE PROFESSIONAL TRAINING AT HIGHER MILITARY EDUCATIONAL INSTITUTIONS (HMEI)}

In accordance with the modern socio-political realities, it is necessary to appropriately develop the military education and train officers of the Armed Forces of Ukraine of a new formation according to advanced military technologies used in military formations of NATO countries. A prerequisite for the success of the modern stage of development of military education is the searching of new methods of training aimed at the formation of a completely developed military personality.

One of the conditions of such successful training at a higher military educational institution (hereinafter referred to as the HMEI) is the use of interactive learning technologies at seminars, as it is typical for the seminars to have a direct contact with cadets, which is particularly important for the effective formation of special knowledge, skills and abilities of future officers. Being one of the of interactive learning technologies, "brainstorming" establishes trust communication, creates in the classroom a friendly atmosphere, mutual understanding between the cadets and the teacher, fully involving students in the discussion activity. Such classes are effective when they are conducted as pre-prepared joint discussions of the issues raised with the group search for answers to them. "Brainstorming" is viewed as a method of solving urgent tasks in a very 
limited time. The essence of the method lies in the fact that it is necessary to express the greatest number of ideas within a small period of time, discuss and carry out their selection. This method is used to develop creative abilities or to solve complex problems. Before the start of the experiment was carried out control measurement of knowledge in the control and experimental groups and the indices were relatively similar. Later, after the experiment, we see on the basis of the comparative analysis of the seminar conducted by the traditional method and method of "brainstorming" that the level of theoretical knowledge in the experimental group at the end of the experiment was more than one and a half points by the five-point assessment scale, and only a small part of the control group improved the quality of knowledge compared to the control evaluation before the experiment. This obviously shows the effectiveness of using the "brainstorming" method in the educational process of vocational training in the HMEI.

Keywords: higher military educational institutions; seminars; "Brainstorming”; serviceme; professional training.

П остановка проблеми у загальному вигляді. Необхідною умовою успішної сучасної військової освіти $\epsilon$ пошук нових прийомів і методик навчання, які направлені на формування всебічно розвиненої особистості військового. Особливим для такої підготовки $€$ використання новітніх технології на семінарських заняттях, тому що для семінарських занять характерним є безпосередній контакт викладача із курсантами, що $є$ особливо важливим для військового вищого навчального закладу (далі ВВНЗ), враховуючи специфіку військової підготовки. Тому дуже важливо встановити довірче спілкування, створити дружню атмосферу, взаєморозуміння, уміло залучити курсантів до дискусії. Такі заняття ефективні тоді, коли вони проводяться як попередньо підготовлені спільні обговорення висунутих питань 3 колективним пошуком відповідей на них.

Актуальністю теми статті $є$ те, що при підготовці у сучасних ВВН3, формуванні професійної культури майбутнього офіцера особливо слід звернути увагу на метод мозкового штурму (мозкової атаки). Мозковий штурм - це метод групового вирішення творчої проблеми. У ході його застосування формується здібність переборювати внутрішні бар'єри, перехід на чужу логіку, внаслідок чого творчі потенціали учасників ніби інтегруються.

Аналіз основних досліджень і публікацій, в яких започатковано розв'язання даної проблеми. Психологію ігрової діяльності у професійній підготовці розкривали С. Рубінштейн, Д. Ельконін та інші науковці. У військовій педагогіці сучасним проблемам військової освіти присвятили праці М. Нещадим, В. Телелим, В. Ягупов; інтерактивні форми та проблемне навчання розкрито у працях: I. Лернера, Л. Кондрашової, А. Нісімчука, О. Падалки, С. Сисоєвої, Н. Тализіної та ін. Також вивчалися теоретичні аспекти, пов' язані з визначенням сугності інтерактивних методів, їх класифікації, ефективності для розв'язаннянавчальнихзавданьІ.Бехом, Л. Виготським, Л. Куликовою, М. Левітовим, А. Матвєєвою,
Д. Ольшанським, С. Рубінштейном, О. Скрипченко та ін.

На думку Н.Ф. Тализіної, сугтєвість сучасної технології навчання, полягає у визначенні найраціональніших способів досягнення навчальної мети. Водночас навчальний процес слід розглядати комплексно як систему, і не можна обмежуватись аналізом лише окремих їі складових. Комплексне використання сучасних методів навчання, технічних засобів навчання i носіїв навчальної інформації є однією з головних особливостей сучасної технології навчання [7, 57]. С. О. Сисоєва зазначає, що “технологія навчання включає сукупність форм, методів, прийомів, методик, засобів, які дозволяють гарантовано досягти запланованого результату. Отже в цьому контексті форми й методи, методики й засоби, прийоми навчання $\epsilon$ тими структурними елементами, з яких конструюється технологія навчання відповідно до цілей і запланованих (бажаних) результатів навчального процесу" [6, 40].

Методологічною основою роботи стали науково-теоретичні дослідження 3 питань використання та впровадження методу “мозкового штурму”: І.Дичківської, В. Мильнікової, В. Мухіної, Т. Сізих, Б. Титаренко, А. Прошиної та ін. Так, Т. Сізих відносить “мозковий штурм” лише до одного з етапів проведення ділової гри, а саме етапу групової роботи над завданням [5]. Розглядаючи данупроблему, дослідник А. Прошина визначає метод "мозкового штурму" як інтерактивний метод навчання. Вона акцентує увагу на тому, що в цьому контексті рольові та ділові ігри, тренінги, кейс-методи, обговорення матеріалу та ін. теж є інтерактивними [3].

Мета статті - розкрити теоретичні основи та практичне впровадження на семінарських заняттях у ВВНЗ при підготовці майбутніх офіцерів методу “мозкового штурму”, як одного із видів інтерактивного навчання. Показати його ефективність на прикладі порівняльного аналізу результатів у вигляді таблиць та графіків.

Виклад основаного матеріалу. Метод мозкового штурму - це спроба знайти рішення 
проблеми за допомогою стимулювання творчої активності. Він полягає в тому, щоб згенерувати якомога більшу кількість варіантів вирішення проблеми, в тому числі і найнеймовірніших. Потім, з усіх придуманих варіантів відбираються ті, які можуть бути реалізовані на ділі.

Метод “мозкового штурму” був розроблений Алексом Осборном в 1953 р. і заснований на допущенні, що однією з основних перешкод для народження нових ідей є “боязнь оцінки”: люди часто не висловлюють вголос цікаві неординарні ідеї через побоювання зустрітися зі скептичним або навіть ворожим до них ставленням $з$ боку керівників і колег. Класична техніка мозкового штурму, запропонована Осборном, базується на двох принципах - “відстрочка винесення вироку ідеї” і “з кількості народжується якість” [1]. Цей підхід передбачає застосування кількох правил. Критика виключається: на стадії генерації ідей висловлення будь-якої критики на адресу авторів ідей (як своїх, так і чужих) не допускається. Працюючі курсанти в інтерактивних групах повинні бути вільні від побоювань, що їх будуть оцінювати за пропонованим ними ідей. Вітається вільний політ фантазії: курсанти повинні спробувати максимально розкріпачити свою уяву. Дозволено висловлювати будь-які, навіть самі абсурдні або фантастичні ідеї. Не існує ідей настільки неоковирні або непрактичних, щоб їх не можна було висловити вголос. Ідей не повинно бути багато: кожного курсата - учасника сесії просять надати максимально можливу кількість ідей. На другому етапі ідеї обговорюються, оцінюються і вибираються ті з них, які визнаються найбільш вірними. Остаточний вердикт щодо проблеми може бути прийнято шляхом явного або неявного голосування. На завершальному етапі відбір кращого рішення провадиться виходячи 3 експертних оцінок.

Критеріями оцінки семінарського заняття проведено у вигляді “мозкового штурму” у ВВНЗ вважаються наступні:

- цілеспрямованість - постановка проблеми, прагнення поєднати теоретичний матеріал 3 практикою;

- планування - виділення головних питань, пов'язаних $з$ профілюючими дисциплінами, ознайомлення з останніми досягненнями науки i техніки за предметом;

- організація роботи - уміння висловлювати власні думки і підтримувати дискусію, конструктивний аналіз усіх відповідей і виступів курсантів, наповнення навчального часу обговоренням проблем, поведінка самого викладача;
- стиль проведення заняття - жвавий, 3 постановкою гострих питань, які виникають у процесі дискусії;

- ставлення викладача до курсантів - 3 повагою, вимогливе лише в межах дозволеного;

- управління групою - викладач швидко встановлює контакт з учасниками семінару, впевнено і вільно тримається у групі, коректно і справедливо взаємодіє зі всіма курсантами;

- висновки викладача - кваліфіковані, переконливі $[1 ; 2]$.

При мозковому штурмі курсанти вільно висловлюють свої думки не хвилюючись, що відповіді можуть бути невірними. "Мозковий штурм' спонукає у курсантів виявляти творчість, розвиває вміння швидко аналізувати ситуацію. За короткий термін (до 3 хв) вдається зібрати велику кількість ідей. На завершальному етапі цієї вправи зібрані ідеї усіма учасниками семінарського заняття, як викладачем так і курсантам на рівних: систематизуються, аналізуються, обговорюються та видікидаються абсурдні. Пропозиції щодо вирішення проблеми зберігаються протягом заняття і використовуються як опорний конспект під час узагальнення і систематизації вивченого матеріалу.

Етапи мозкового штурму. Перший етап приймають будь - які дії, обмежений часом або кількістю ідей. Другий етап - оцінювання, обговорення, рейтингування, класифікація ідей мозкового штурму і має назву “Карусель”. Цей метод ефективний як метод одночасного залучення до навчання всіх учасників процесу. Дану технологію застосовують для:

а) обговорення гострої проблеми;

б) збирання інформації з певної теми чи проблеми;

в) інтенсифікації перевірки обсягу знань.

Для майбутнього офіцера цей метод має велике значення, оскільки дозволяє приймати відповідальне рішення в напружених умовах, коли існує дефіцит інформації або, навпаки, надлишкове і суперечливе інформаційне поле. Це створює додаткову нервово-психологічну напругу. Тому $з$ метою формування нервово-емоційної стійкості в процесі підготовки сучасного бойового офіцера з успіхом може застосовуватися метод "мозкового штурму".

Цей метод використовується для розвитку творчих здібностей або для розв'язання складних проблем, його можна використовувати в різних формах діяльності: у роботах 3 малими групами, командами, великими групами ("гра 3 глядачами"), індивідуальній роботі віч-на-віч [3].

При використанні на семінарських заняттях у 
ВВНЗ звичайних прийомів обговорення та розв'язання проблем виникненню новаторських ідей перешкоджають контролюючі механізми свідомості, які сковують потік цих ідей під тиском звичних, стереотипних форм прийняття рішень. Активну роботу курсантів можугь стримувати такі фактори: страх перед невдачею, побоювання видатися смішним тощо. Для нейтралізації цих факторів проводиться мозковий штурм, який поєднує евристичний діалог та метод вільних асоціацій [5].

Використання методу “мозкового штурму” в практиці навчання у ВВНЗ можливе за дотримання певних правил, які потрібно враховувати під час проектування та реалізації заняття. До цих правил належать такі:

- висловлення думок повинно відбуватися без закріпачення, навіть якщо запропоноване розв'язання спочатку видається абсурдним і недоречним;

- пропоновані думки не можна обгрунтовувати в момент їхнього виголошення під жодним приводом;

- висловлені ідеї не можна коментувати. Це стосується однаково як організатора заняття, так і інших учасників дискусії;

- після закінчення списку ідей допускається обгрунтування висловлених пропозицій розв'язання проблем;

- висловлення ідей (думок) може відбуватися в письмовій формі, а також анонімно;

- усі висловлені думки повинні детально записуватися (реєструватися);

- за один раз можна висловлювати тільки одну думку [4].

Умови ефективності мозкового штурму:

- максимальна зацікавленість усіх учасників у досягненні результату;

- абсолютний авторитет керівника в організації роботи;

- чітке дотримання правил проведення мозкової атаки.

Основні принципи мозкової атаки:

- не критикувати - можна висловлювати будьяку думку без побоювання, що вона буде невдалою;

- стимулювати всяку ініціативу - чим незвичайнішу, тим краще;

- прагнути до найбільшої кількості ідей;

- змінювати, комбінувати, покращувати запропоновані ідеї (свої та чужі).

Метод “мозкового штурму” відносять до групи інтерактивних методів навчання й використовують для вирішення конкретних практичних завдань.

Найкращим способом оцінювання висловлених ідей на заняттях $є$ голосування всіх учасників 3 попередньою загальною дискусією. Провести голосування можна на тому ж занятті після короткої перерви або на наступному занятті (це залежить від кількості висловлених ідей, складності проблеми, наявності навчального часу тощо). Однак найдоцільнішим є завершення роботи протягом одного заняття за умови повного “занурення" курсантів у навчальну ситуацію. За браком часу можна запланувати спарене заняття (4 академічні години).

За дотримання описаних правил і застережень проведення заняття методом мозкової атаки в умовах навчального закладу може здійснюватися за такою структурою:

Перший етап

Крок 1

- Вступ. Окреслення проблем, завдань.

- Формулювання проблем, завдань, задач (через проміжок часу в 5-10 хв).

Крок 2

- Висловлення думок, ідей.

- Реєстрація ідей.

Другий етап

Крок 3

- Обгрунтування своєї ідеї тими, хто висловив пропозиції щодо розв'язання проблеми.

- Загальна дискусія над запропонованими ідеями (правильність, реальність, оригінальність).

- Остаточний вибір найкращої ідеї.

Крок 4

- Обгрунтування остаточного вибору.

- Підсумовування проведення заняття, підкреслення моментів, що мають важливе дидактичне значення.

Основним завданням занять $€$ формування вміння курсантів генерувати ідеї в умовах екстремальної ситуації, висловлювати та обгрунтовувати свої думки. Для цього необхідно дотримуватись певних правил їх проведення:

1. Чітко сформулювати проблему (завдання). Визначити потреби та мету іiі розв'язання.

2. Ознайомити курсантів 3 умовами й правилами проведення роботи. Визначити групи курсантів (команди, бригади, експертні групи тощо), пояснити їхні завдання.

3. Стимулювати генерацію ідей у робочих групах. Ідеї повинні бути новими, простими, надійними, доступними.

4. Організувати мозковий штурм поставленої проблеми за певний проміжок часу $(10-15$ хв). Можете регламентувати кількість відповідей, що їх потрібно отримати $(5,7,10$ тощо).

5. Провести репрезентацію ідей, запропонованих учасниками, та їх аргументацію. 


\section{МЕТОДИКА ВИКОРИСТАННЯ “МОЗКОВОГО ШТУРМУ” НА СЕМІНАРСЬКИХ ЗАНЯТТЯХ В ПРОФЕСІЙНІЙ ПІДГОТОВЦІ У ВИЩИХ ВІЙСЬКОВИХ НАВЧАЛЬНИХ ЗАКЛАДАХ (ВВНЗ)}

6. Організувати аналіз ідей, який можна здійснити за допомогою морфологічної таблиці.

7. Допомогти курсантам відібрати кращі ідеї, спрямуйте їхнє подальше розроблення.

Для проведення мозкового штурму всі учасники розподіляються на декілька груп. Організатор пояснює правила мозкового штурму курсантам, формулює проблему та завдання для кожної групи учасників. Кожна група пропонує свої ідеї-рішення (мінімум три ідеї від кожної команди), які записуються на листі або дошці. Далі відбувається обговорення ідей. Кожна команда обгрунтовує свої ідеї та можливості їхнього впровадження в життя.

Після цього здійснюється відбір ідей 1-й етап - засідання групи. Кожен учасник висловлює щодо запропонованої теми будь-які думки, не контролюючи їхнього ходу, не оцінюючи їх як істинні або хибні, дивні та несуттєві. При цьому всі намагаються спонукати один одного до подібних вільних асоціацій ідей.

2-й етап - загальна маса висловлених ідей аналізується з тим розрахунком, що серед них виявиться декілька, які містять найвдаліші рішення.

Підбиття підсумків семінарського заняття 3 використанням методу “Мозкового штурму" в експериментальній і контрольній (традиційна форма проведення) групі зведено у таблицю 1 i графічно зображено на рисунку 1.

Таблиця 1.

Підбиття підсумків практичного заняття

\begin{tabular}{|c|c|c|c|c|}
\hline \multirow{2}{*}{$\begin{array}{c}\text { Математичні } \\
\text { показники }\end{array}$} & \multicolumn{2}{|c|}{ Експериментальна група } & \multicolumn{2}{|c|}{ Контрольна група } \\
\hline & $\begin{array}{c}\text { початок } \\
\text { експерименту }\end{array}$ & $\begin{array}{c}\text { кінець } \\
\text { експерименту }\end{array}$ & $\begin{array}{c}\text { початок } \\
\text { експерименту }\end{array}$ & $\begin{array}{c}\text { кінець } \\
\text { експерименту }\end{array}$ \\
\hline $\bar{X}$ & 3,35 & 5,0 & 3,4 & 3,75 \\
\hline$\delta$ & 0,99 & 0 & 0,82 & 0,68 \\
\hline $\mathrm{m}$ & 0,22 & 0 & 0,18 & 0,15 \\
\hline
\end{tabular}

голосуванням. Кожен учасник має право вибрати три ідеї із загального переліку. Учасники підходять до ватману й проти ідеї, яка їм найбільше сподобалася, ставлять крапку маркером / крейдою (1 крапка - 1 голос). Для прийняття остаточного рішення організатори підраховують кількість голосів за кожну ідею. Після цього проводиться ранжирування результатів - курсанти обирають декілька ідей (дві-три ідеї), які отримали найбільшу кількість голосів і являють собою найефективніші напрями розв'язання проблеми. Ці ідеї обговорюються всіма учасниками, а після обговорення визначаються способи їхньої реалізації.

Вважаємо доцільним навести приклад застосування методу мозкового штурму у навчальному процесі професійної підготовки офіцерів у ВВНЗ за темою практичного заняття "Супільство як система. Соціально-економічні зміни і розвиток супільства”.

Практичне заняття проводиться у вигляді круглого столу, тема обговорення якого відповідає темі практичного заняття - Суспільство як система. Соціально-економічні зміни і розвиток суспільства.

Основною тематикою яка розглядається $є$ суспільство в Україні в умовах становлення демократичної незалежної держави.

В круглому столі приймають участь всі курсанти групи.
Висновки: як ми бачимо з рисунку 1 , що рівень теоретичних знань у експериментальній групі, де використовувались на практичних заняттях інтерактивні методи навчання у вигляді “мозкового штурму”, на кінець експерименту збільшився на півтора бали за п'ятибальною шкалою оцінки, а контрольній групі лише незначне поліпшення якості знань. Це вочевидь показує ефективність застосування методу “мозкового штурму” в освітньому процесі ВВНЗ.

Висновки. Отже, узагальнюючи вище сказане, слід підкреслити, що використання методу “мозкового штурму” у освітньому процесі ВВНЗ створює умови для розвитку самореалізації особистості та допомагає досягти високого інтелектуального розвитку курсантів, майбутніх офіцерів - захисників Вітчизни. “Мозковий штурм” $є$ прекрасним методом, щоб використати досвід учасників 3 метою розв'язування проблем і розробки ідей.

Перспективи подальшого дослідження особливості використання інтерактивного навчання викладачами військово-спеціальних дисциплін полягають в аналізі досвіду використання інтерактивного навчання в різних навчальних закладах, а також визначення основних напрямів та шляхів запровадження інтерактивного навчання в навчальному процесі BBH3. 


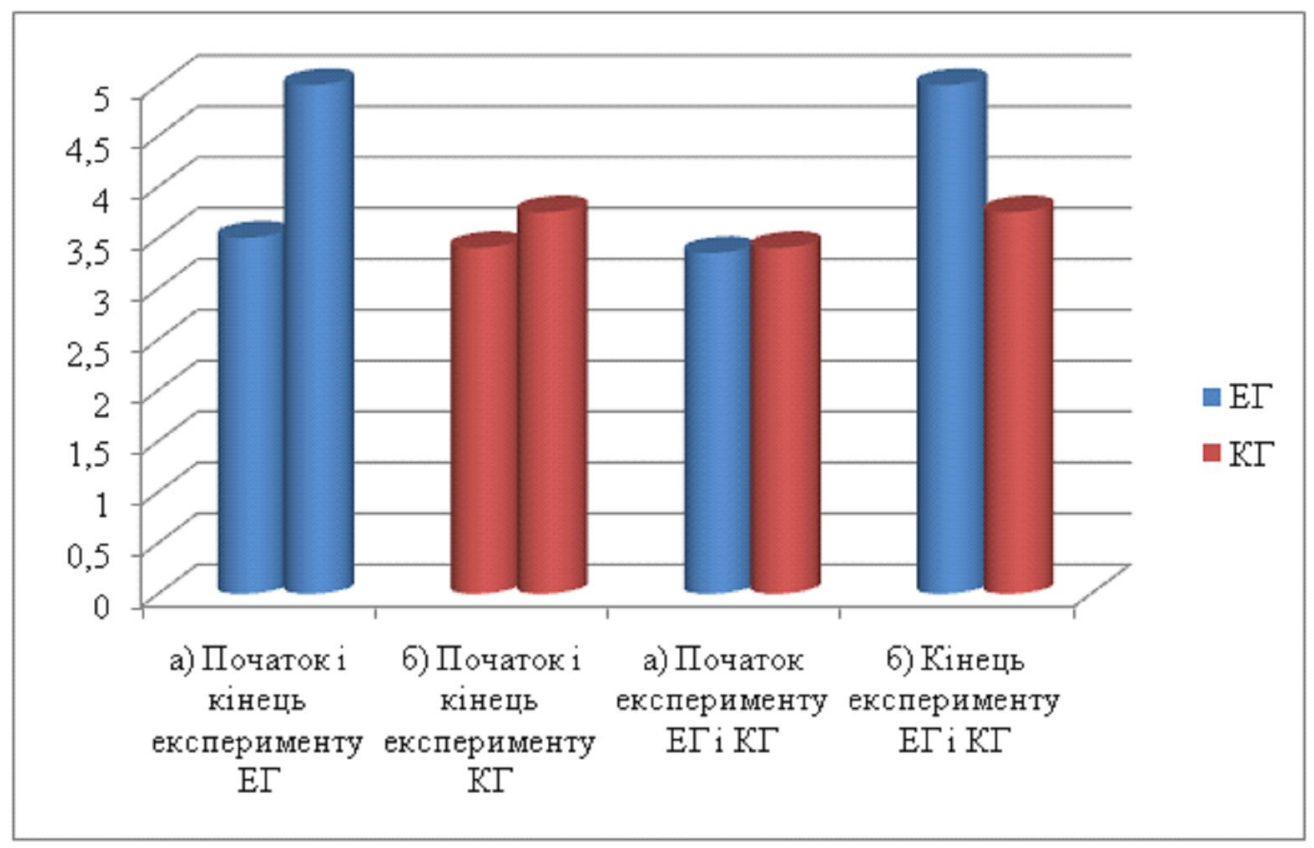

Рис. 1. Графічне зображення підбиття підсумків практичного заняття на початку та у кінці експерименту

\section{ЛITEPATУРA}

1. Alex F. Osborn Applied Imagination: Principles and Procedures of Creative Problem-Solving. New York: Charles Scribner's Sons, 1953.

2. Нісімчук А. С. Сучасні педагогічні технології / А. С. Нісімчук, О. С. Падалка, О. Т. Шпак. - К., 2000. -368 c.

3. Прошина А. Н. Использование интерактивных технологий в высшей школе как условие интенсификации образовательного процесса / А. Н. Прошина // Труды Санкт- Петербургского государственного университета культуры и искусств. - Вып. 1. - Т. 200. - 2013. - С. 287290.

4. Рижиков В.С. Теорія і практика конструювання цільових моделей (професіограм) та процесу пофесійної підготовки майбутніх юристів: Монографія / Рижиков В.С. - Херсон: вид-во “Айлан”, 2010. - 280 с.

5. Сизых Т. В. Деловая игра как способ развития социальной компетентности обучающихся / Т.В. Сизых // Педагогика: традиции и инновации: мат. междун. науч. конф. (г. Челябинск, октябрь 2011 г.). T. 1. - Челябинск: Два комсомольца, 2011. С. $151-153$.

6. Сисоєва С. О. Інтерактивні технології навчання дорослих: навч.-метод. посіб./ С.О.Сисоєва; НАПН України, Інститут педагогічної освіти і освіти дорослих. - К. : ВД “ЕКМО”, 2011. - 320 с.

7. Талызина Н. Ф. Управление процессом усвоения знаний / Н. Ф. Талызина. - М.: Изд-во МГУ, 1975. - 343 с.

8. Ягупов В.В. Теорія і методика військового навчання: [монографія] / В.В. Ягупов. - К.: Тандем, 2000. - 380 с.

9. Ягупов В.В. Педагогіка: навч. посіб / В.В.Ягупов. - К.: Либідь, 2003. - 560 с.

\section{REFERENCES}

1. Alex, F. Osborn Applied Imagination: Principles and Procedures of Creative Problem-Solving. New York: Charles Scribners Sons, 1953.[in English].

2. Nisimchuk, A. S., Padalka, O. S., Shpak, O. T. (2000). Suchasni pedahohichni tekhnolohii [Modern pedagogical technologies]. Kyiv, 368 p. [in Ukrainian].

3. Proshina, A. N. (2013). Ispolzovanie interaktivnykh tekhnologiy v vysshey shkole kak uslovie intensifikatsii obrazovatelnogo protsessa [Using interactive technologies in higher education as a condition for intensifying the educational process]. Proceedings of the St. Petersburg State University of Culture and Arts. Issue 1, Vol. 200, pp. 287-290. [in Russian].

4. Ryzhykov, V.S. (2010). Teoriia i praktyka konstruiuvannia tsilovykh modelei (profesiohram) ta protsesu pofesiinoi pidhotovky maibutnikh yurystiv: Monohrafiia [Theory and practice of designing target models (professiograms) and the process of professional training of future lawyers: Monograph]. Kherson: vyd-vo "Ailan”, 280 p. [in Ukrainian]. 
5. Sizykh, T. V. (2011). Delovaya igra kak sposob razvitiya sotsialnoykompetentnosti obuchayushchikhsya [Business game as a way of development of social competence of students]. Pedagogika: traditsii $i$ innovatsii: mat. mezhdun. nauch. konf. ( $g$. Chelyabinsk, oktyabr 2011 g.) - Pedagogy: traditions and innovations. ap. sci. Conf. (Chelyabinsk, October 2011). (pp. 151-153). Vol. 1, Cheliabynsk: Dva komsomoltsa. [in Russian].

6. Sysoieva, S. O. (2011). Interaktyvni tekhnolohii navchannia doroslykh: navch.-metod. posib. [Interactive adult learning technologies: tutorial manual]. National Akademy of Educational Sciences of Ukraine, Institute of Pedagogical Education and Adult Education. Kyiv: VD "EKMO”, 320 p. [in Ukrainian].

7. Talyzina, N. F. (1975). Upravlenie protsessom usvoeniya znaniy [Managing the learning process]. Moscov: Yzd-vo MHU, 343 p. [in Russian].

8. Iahupov, V.V. (2000). Teoriia i metodyka viiskovoho navchannia: monohrafiia [Theory and methodology of the military training: Monograph]. Kyiv: Tandem, 380 p. [in Ukrainian].

9. Iahupov, V.V.(2003). Pedahohika: navch. posib [Pedagogy: study guide]. Kyiv: Lybid, 560 p. [in Ukrainian].

Стаття надійшла до редакції 26.03.2018

УДК 378.147:81’243

DOI:

Ірина Волошанська, кандидат педагогічних наук, доиент кафедри мовної та міжкультурної комунікації Дрогобицького державного педагогічного університету імені Івана Франка Зоряна Хало, кандидат педагогічних наук, доцент кафедри мовної та міжкультурної комунікації Дрогобиџького державного педагогічного університету імені Івана Франка

\section{ОСОБЛИВОСТІ НАВЧАННЯ ІНОЗЕМНОЇ ПРОФЕСІЙНОЇ КОМУНІКАЦІЇ СТУДЕНТІВ ВНЗ}

У статті охарактеризовано особливості навчання іноземної професійної комунікаиї студентів ВНЗ. Проаналізовано активні методи навчання професійної комунікації на заняттях іноземної мови. Доведено ефективність застосування комунікативних підходів унавчанні при індивідуальних, колективних та групових формах роботи. Розкрито сутність та специфіку діалогічного мовлення та мовленнєвих ситуацій з метою формування іноземної професійної комунікації майбутніх фахівців. Виокремлено сприятливі психологічні умови для проведення занять. Вказано на можливості вивчення лексичного матеріалу за допомогою активних методів та читання. Виявлено шляхи ефективного навчання іноземної професійної комунікації на заняттях іноземної мови.

Ключові слова: навчання; іноземна мова; професійна іноземна комунікачія; активні методи; комунікативні підходи; мотивація.

Jim. 7.

Iryna Voloshanska, Ph.D.(Pedagogy), Associate Professor of the Language and Intercultural Communication Department Drohobych Ivan Franko State Pedagogical University

Zoryana Khalo, Ph.D.(Pedagogy), Associate Professor of the Language and Intercultural Communication Department Drohobych Ivan Franko State Pedagogical University

\section{THE SPECIFICITIES OF TEACHING THE FOREIGN PROFESSIONAL COMMUNICATION TO THE STUDENTS OF HIGHER EDUCATION ESTABLISHMENTS}

The article deals with the specificities of teaching the foreign professional communication to the students of higher education establishments. The main task of higher education establishments is to teach the students to use the foreign languages while thinking and communicating in business and professional situations. It gives them the opportunity to learn cultural, economic, medical achievements of other countries and use the gained experience in Ukraine. The active methods of teaching the professional foreign communication have been analysed. The efficiency of applying the communicative approaches to studying foreign languages in the individual and group forms of work has been proved. It adapts the students to real communicative situations, intensifies their activities and stimulates the students'foreign speech development. The authors suggest creating the professional situations and games while teaching foreign languages and using such technologies, as "Brainstorm", "Microphone", "Unfinished Sentences". "Replication" is another method to teach the foreign 